\title{
Syntagmatic And Paradigmatic Features Of Relative Syntagmas In Azerbaijani And English Languages
}

\author{
Hashim L. Akbarov, PhD Candidate \\ Lankaran State University, Lankaran, Azerbaijan
}

doi: 10.19044/esj.2016.v12n20p214 URL:http://dx.doi.org/10.19044/esj.2016.v12n20p214

\begin{abstract}
The article deals with the definition of syntagma and relative syntagmas in Azerbaijani and English languages. At the same time, they are researched as syntactic units of linguistics. They are classified according to their types. Also, their meaning is spoken of widely in the article. It also talks about the semantic and stylistic features of syntagma as a unit of syntax. Syntagma is investigated as a syntactic unit of linguistics. Also, it comprehensively highlights its importance. This unit consisting of two members of the combined words is used in the functions of determining and being determined. It is explained as a semantic-syntactic event, and it studied and developed its semantic features. Signs perform the system of approaches in the form of syntagmatics and paradigmatics. Syntagmatic approaches are based on distributive potentials of signs. Their valence, but paradigmatic approaches are based on the selection of definite element of paradigm signs. Thus, this is the reason Saussure considers the morphology as the "sphere of paradigmatics". The syntax is, however, known as the "sphere of syntagmatics". A notion of "verticality" and "horizontality" exists even in the row of language signs of classic linguistics. Therefore, syntagmatics is explained as a "horizontality", but paradigmatics as a "verticality”.
\end{abstract}

Keywords: Relative syntagmas, syntagmatic relations, paradigmatics, semantic-syntactic, valence

\section{Introduction}

The modern position of language schools of the post-Soviet period, one of which is the Azerbaijani language, is experiencing a paradigmatic shift stage. Changes in language always proceed slowly, and they get fixed to the theoretical linguistics even more slowly. Problem analysis of relative syntagmas in Azerbaijani linguistics is subjected to the simultaneous actions of several schools in different directions. A fundamental factor is the aspect that the relative syntagma, which received support from the national 
linguistic school, were created under the influence of Russian theories and Russian versions of relative syntagma in Azerbaijan studies a long time. The process of globalization in the world brings the world's languages together. This process occurs regardless of the schools to which the language groups belong. This circumstance is connected to communication problems and the development of dialogue at all levels of linguistics. Nowadays, theories of dialogue are mostly in demand; and as such, they are intensified in all schools. On the other hand, the Azerbaijani school of relative syntagma reveals the tendency to preserve national sources. This is due to the problem of language culture of confrontation absorption, the overall process of Europeanization, and the Americanization of language culture. Only now does Azerbaijani relative syntagma have the opportunity to directly initiate similar processes in Turkic studies. Interference is due to common language roots and simultaneous multi-vector influences of Eastern and Western theories belonging to a linguistic tradition. Hence, this is as expressed in literature and oral discourse. In this work, special attention is drawn to the existence of relative syntagma in speech and journalism discourse, which are more expedient. Only now has it created the prerequisite objective of structural research of relative syntagma in the native Azerbaijani language. The Russian linguistic theories, V. Scherba and V. Vinogradov, determined the syntagma associated with speech acts. Thus, this is with phonetic and rhythmic characteristics of the information unity, interconnected information, and the tempo of speech. In modern Russian language schools, paradigmatic shift of research of syntagmas occur. Furthermore, similar processes characterize the Azerbaijani language school. This process is explained by a common interest in structural linguistics.

Therefore, the primary function of language is an act of communication. Therefore, it is social, and it also creates a communication process between people. The regulation of language, its ways of description, and the search for patterns of development of languages in the period of globalization is particularly relevant. This is because the main purpose of national languages is the possibility and the necessity of conducting intercultural dialogue at all levels. Modern theoretical linguistics has noted the trend towards convergence and cross-language dialogue expressed by the presence of languages in different linguistic groups. They have also identified the emergence of similar clichés, which, on one hand, makes the language more clear. On the other hand, however, the language is losing linguistic identity, linguistic inevitable forces of globalization. National postSoviet school of the theory was introduced into the syntagmatic achievements of French, German, and American linguists. This interest is due to the increasing intensity of the theory of dynamic semantics (Kleber). Therefore, this process is manifested in the vector of its multidirectional 
relations in all linguistic levels: phonetics, pronunciation, vocabulary, morphology, and to a lesser extent, syntax. A sentence is a complete unit of human speech, which concludes the unity of semantic and grammatical meaning. This is the basic definition of a sentence. There are other definitions of a sentence based on the development of linguistic definition systems. Therefore, they offer a more complicated and differentiated understanding. All these grammatical processes and phenomena are closely linked. In addition, they have a syntactical nature.

\section{Scientific Novelty}

The very formulation of the question in such a plan is considered to be relevant and innovative. This is because it does not only have linguistic meaning, but also goes far beyond the scope of a particular area. Ontological self-determination of Azerbaijani relative syntagmas at the contemporary stage is that the three vectors take effect during the process of its formation: Russian, European and Turkic. This requires revision and the organization of these schools in order to determine their own linguistic norms of relative syntagmas in Azerbaijani language. From this point of view, the theory of relative syntagmas has not been studied in the Azerbaijan linguistics. It was in this that we see the innovation that takes place in this paper. The syntax, as a branch of linguistics, is engaged in researching words and phrases in this regard as reflected in its modern paradigmatic tendency to identify the intercultural dialogue at the language level. Syntactic syntagmas in this sense have a special role. In today's schools, there is conflicting theoretical linguistics to the definition of syntagmas. Hence, this is due to the versatility of the syntagma as a grammatical category.

\section{Materials and Methods}

The methodological base of the research is an integrated approach to the study of the syntagma. Historical method, comparative - typological analysis, and linguistic analysis of the text were used here. Similar problems have demanded the creation of a methodological complex, in addition to the input linguistic theories and contemporary developments related disciplines: psycholinguistics, sociolinguistics, discourse receptive theories, culture, and psychology. The entering of mixed theories explains modern integration in the field of language, philosophy, literature, and culture. This is based on the fact that the language is manifested at all stages of the language of the personality as an individual, in terms of the functioning of the society (A.A Akhundov, G. Kazimov, Y. Seyidov, F. Veysalli, F. Aslanov etc.). This methodological approach is the inevitability of routinization. Syntagma is derived from the Greek language, in which the theoretical interpretation of the syntagma refers to the rhetorical figure of the language. According to 
Greek rhetoric, syntagma is defined as a word, group of words, or a whole sentence.

In the paper, effort was made to identify syntagma historically. The concept of the term, and its functions in the regulatory field of the Azerbaijani language was also identified. Some difficulties in solving this problem resulted in different approaches to research on comparative linguistics. Its task includes adequate description and interpretation of the operation of the syntagma in the Azerbaijani language. Thus, this is in terms of the specific features of the language in an effort to explore the linguistic comparative-typological aspect of language universals in comparison with English language. The differences in languages, especially clearly expressed in the phraseologisms, are reflected in the features of a native speaker of verbal thinking and verbal discourse.

This provision is expressed in the works of many Russian, Azerbaijani, and foreign linguists (V.V. Vinogradov, V.N. Yartsev, V.G. Gak, A.D. Raykhshteyn, A.A. Ufimtsev, G.S. Schur, N.Y. Trir, E.M. Solodukho, A.A. Akhundov, G. Kazimov, Y. Seyyidov etc.). Subsequently, this methodological approach is due to the term routinization. Thus, this term is inevitable.

From the research works written about syntax, it is known that this field of science is busy with the investigation of word combinations and sentences. In this regard, according to some scientists (F.de Saussure, Sh. Bally, F. Mikush, B.V. Tomashevsky, S.I. Kartsevsky, V.V. Vinogradov, A.A. Akhundov), syntax is being understood as the field of science about syntagmatic relations and syntagmas. Thus, a question appears. What is the syntagma?

"The word "syntagma” comes from the Greek (-syntaqma - literally something to unite) -linguistics.

1) Decisive element with the meaning of the element and emphasis, appointed by the combination of words and word parts, for example: Rus. везущий воду - водовоз;

2) Word or word group;

3) Whole syntactic intonation and a unit of meaning” (Jaffarov, Garayev \& Jaffarova, 1981; Словарь иностранных слов (1949)).

As can be seen, the origin of syntagma belongs to the Greek language. Here, the theoretical interpretation of the syntagma referred to the rhetorical figure of the language. According to Greek rhetoric, "syntagma” is defined as a word, group of words, or a whole sentence. The word "syntagma" is of the Greek origin which means to "connect to something". Therefore, the question is translated and explained in linguistics as follows:

1) Words or phrases that are formed by defining the semantic connections and detectable element, e.g., Rus. совхоз, колхоз 
2) Word or group of words;

3) A holistic syntactic or semantic intonation unity.

Thus, our understanding of the syntagma is as follows:

Syntagma is composed of two members of the joint. It serves as the function of determining and being determined. It is used in the oral language, i.e. in oratory. Sentences are divided into certain rhythmic groups, which are determined by the phonetic syntagma. It is possible that analogically words are divided into syllables. In general, the term "syntagma" in linguistics has many meanings. For example, O.S. Akhmanova gave six definitions of "syntagma" in her dictionary of linguistic terms (Ахманова, 1966). Furthermore, syntagma in semantic context is a group of rhythmic words. In this case, syntagma is represented as a phonetic phenomenon. This aspect of syntagmas is analyzed in detail in the works of M. Gramm, L. Shcherba, V.V. Vinogradov, A.N.Gvozdev, and others.

In fact, the problem of syntagma does not have a long history in linguistics. Even independent scientific research works have not been written about this question. However, it should be noted that this area created too many ideas. Also, there is a serious difference between linguistic specialists and researchers.

Thus, there are many different approaches to the definition of the syntagma. Although speech segmentation is a more phonetic character, i.e. related to the mechanism of pronunciation, partitioning in our speech on the different parts are based on grammatical and semantic effects of regularity.

In linguistics, there are other approaches in determining the syntagma. The existing concept of modern science binomial syntagmas is associated with the name of the famous Swiss philosopher and linguist Ferdinand de Saussure. They identified the syntagma as a connection or association of two or more characters. Consequently, they make words, phrases, sentences, or sentence member to be complex. Another outstanding linguist, Baudouen de Kourtene, also used the syntagma as a word.

In science, there were also approaches which were discussed. An example of this approach is the syntagma which is regarded as a syntactic phenomenon in the works of Sh.Bally, S.O. Kartsevsky, F.F. Fortunatov, B.V. Tomashevsky etc. These linguists believe that the syntagma can be divided rhythmically and linearly together inside its members in another word. Syntactically, syntagma is indivisible. This is because in this case, the members of syntagmas act together to form a single meaning.

For comparison, brother's book - green (color, valuable) - which was looking new was bought two years ago in Bucharest.

Syntagma is regarded as unity. It is formed by combining two members which has two functions. One of the members acts as "defining", while the other acts as a "definable one". 
Here, the syntagma can act as words and phrases, morphemes, and separate sentences. Examples include: to buy a car; green trees of the forest of our village; If you became a miller, call for brave Koroghlu (Azerbaijani proverb).

Syntagma has been described by some other scientists. For example, Ferdinand de Saussure has described it in a word (re-lire), phrase (de grace), or sentence (il ya) in the presence of the members to create any complex combination or junction of two or more signs (Соссюр, 2004). Consequently, Badouen de Kurtene has used the syntagma in the meaning of “word” (Бодуэн де Куртэнэ, 1963). Some French phonetists (especially, P.Passy- H.A.) referred to the syntagma as a group of breathing. L.V.Scherba considers syntagma as the completeness of the meaning of rhythmic groups of words in a sentence (Щерба, 1953). Furthermore, V.V. Vinogradov writes about syntagma: "It is very difficult to find two scientists who understand and give the same meaning to this term" (Виноградов, 1952).

Thus, it appears that syntagma can be called both phonetic and syntactic unit. In linguistics, there are different opinions about syntagma. Some linguists believe that syntagma is a group of words rhythmically combined and which expresses a complete thought (L.V. Scherba, V.V. Vinoqradov). In addition, others (F. de Saussure, Sh.Bally, F.Mikush, B.V.Tomashevsky, S.I. Kartsevsky) referred to syntagma as not a phonetic, but as a syntactic event. Academician L.V. Scherba is the founder of the theory of syntagma. Thus, he named it phonetic event. He shared his clear thoughts on this new sense. L.V. Scherba writes: "In the process of speechviews integrity, expressing a single meaning wholeness consists of a rhythmic group, including several phonetic units, I call them syntagma" (Щерба, 1953).

It should be noted that in the same book at page 84, L.V. Scherba has given the syntagma as a "phrase" and "rhythmic group" together with the headlines "syntactical segmentation of the flow of speech". It is obvious that though L.V. Scherba was spoken from a phonetic point of view, at the same time, he shows that the syntagma is connected with syntax and it connects with phonetics according to the condition of pause and stress in the process of syntactic event. As a result, syntagma is marked as a syntactic and phonetic event.

L.V. Scherba also noted the syntagma as the idea of integrity as well. He shows that syntagma at the same time is a semantic-syntactic unit. Scherba's learning of syntagma still shows its strength. This is however just as A.N. Gvozdyev considers the syntagma as L.V.Scherba shows (Гвоздев, 1958). 
In one of his articles, the academician V.V.Vinogradov has noted the syntagma to be full of syntactic unit. He opined that it should be approached from this point of view. In another article, he stated: "Syntagma is the main category of stylistic syntax." (Ученые записки Московского Университета, вып. 150, 1952)

Subsequently, A.A. Reformatsky has approached the syntagma from other aspect. He has given the following definition to it: "Syntagma is the combination of two other members in the relationship of subordination" (Реформатский, 1955). While saying two members, he meant two words, namely: two members of sentence. A.A. Reformatsky's thoughts and opinions about syntagma coincide with that of Saussure. Thus, we can say that their instructions (teaching) have not brought anything new to the world of linguistics. A.A. Reformatsky also showed some types of internal syntagma in the Russian language.

1) With derived word generated, for example, syntagma сад - being determined (the root of the word), and ик - determined (endings).

2) Consists of compound word, for example, syntagma паровоз, колхоз, совхоз, водовоз, etc. These are simply lexemes. According to the author, it has no importance for syntax. Thus, some characteristic or features of syntagma are as follows:

o Syntagma combines two members;

o This and other member of syntagma can belong to other syntagma;

o There is a subordination relationship between components of syntagma.

Furthermore, subordination relationship can mostly be found in complex sentences. As mentioned above, though syntagma is a unit of syntax (namely syntax - H.A.), it does not learn only syntagma, but also explores sentences. Therefore, taking a look at one example:

Young doctor examined the patients thoroughly.

- In the sentence:

1) Young doctor, 2) doctor examined, 3) examined, 4) examined the patients, 5) the patients, 6) examined thoroughly.

- We have these syntagmas which clearly shows that these syntagmas are built on the basis of the following relations:

the first one is in the attributive relation, the second one is in the predicative relation, the third one is in the predicative relation, the fourth one is in the predicative relation too, the fifth one is in the attributive relation, the sixth one is in the relative relation.

Therefore, it was noted that two member syntagmas was built up in the relationship of subordination. The word doctor two times has been used 
in the composition of four syntagmas, while the word examined has been used four times. Based on this example, it can be concluded that the syntagmas differ from the word combinations according to the breadth of their coverage area. Here, it is only one of the syntagmas (young doctor). However, this is the same with syntactical combinations. Predicative combinations and being a two member syntagmas, once again shows that they are like phrases (word combinations). Also, it confirms that syntagma is a unit of syntax.

Academician A.A. Akhundov considers the syntagma as a unit of the level of syntax. On the other hand, A. Rajably considers this statement to be untrue. He shows the two units of the level of syntax. "1) Word combinations as a syntactic model which consists of the forms of words based on syntactic connection and syntactic meaning. 2) Sentence given as a syntactic model consists of the combination of sentence model of the forms of word and word combinations" (Rajably, 2003). From this point of view, A.A. Akhundov's thoughts about syntagma are more interesting. He writes: "First of all, syntagma is considered as a phonetic unit, and is used based on the meaning of rhythm, intonation, and speech flow. Secondly, syntagma is used based on the meaning of the result of syntactic stylistic segmentation. Thus, in this case, it is regarded as a stylistic unit, consisting of determined and being determined binomial structural meaning” (Akhundov, 1988). As a unit of syntax, the same syntagmas is divided into two groups, namely: 1) predicative, and 2) non-predicative syntagmas. The predicative syntagmas are the same in accordance with the sentence. As a rule, they are communicative. Furthermore, there is one predication. Thus, nonpredicative syntagmas cover only word combinations. They usually have a nominative (naming) nature.

As known, non-predicative syntagmas are divided into three parts: attributive, objective, and relative. Attributive syntagmas are the syntagmas established by the relation of approach. Objective syntagmas are formed by the management relation. Relative syntagmas are based on foreign relationship. Thus, it can be concluded that the predicative relations creates the syntagma by expressing a certain opinion. For example:

It is raining. My uncle returned from Bucharest. My friend works in the village etc.

Consequently, non-predicative relation is the relation which does not denote a predication. However, this relationship serves as the formation of three types of syntagmas. They are:

1)

Attributive - namely, determining word is an attribute. We can give as an example to such syntagmas the (first) type substantive combinations in the Azerbaijani language. For example, 
Golden ring, red shirt, green grass, cold room, and so on (there is a relation of approach).

2) Objective - namely, the determining word is an object. For example, to read a novel, to learn the words, to tell a lie etc (it is created by management relationship).

3) Relative - that is, the determining member of the predicative (verb predicate) expresses a definite quality. Relative syntagma is the syntagma which is formed by verb and the combination of adverb denoting its manner of action. For example, to run quickly, to write well, to run fast.

Subsequently, they are developed as word combinations. For example, to read rapidly, to talk kindly, to smile gently, and so on (it is formed by external approach).

As mentioned above, these different relation types between members of syntagm, once again prove that it (namely syntagma - H.A.) is the unit of syntax. However, Professor A. Rajably is against this opinion. He stated that there are only two types of syntax level. They are word combinations and sentences.

The problem of syntagma is the new one to the Azerbaijani linguistics. As a result, some scholars are generally not talking about it. Some are just overcoming it, while others stated that it is not so important for linguistics.

Professor Yusif Seyyidov's thoughts of syntagma, almost coincides with the opinion of Professor A. Rajably's. According to his mind, syntagma consists of words. Hence, this is why it cannot be considered a unit of phonetics. At the same time, he does not also include the syntagma to the syntax. As A.Rajably writes, Yusif Seyyidov stated that syntax has two investigation objects - 1) word combinations and 2) sentence. He notes that "being in case of the permanent forms developed from the grammatical structure of language of syntactical events, syntagma does not have such forms; and it can provide itself in any form at every chance" (Seyyidov, 1992). Y. Seyyidov notes that syntagma is mostly connected with rhetoric, art scene, and oral speech culture. According to his notes, syntagma can also be organized with words which have no grammatical relations with each other. In this regard, he generally does not want to talk about the relation forms of words in syntagma. However, at the end, he comes to a conclusion that word combination is formed by the semantic-syntactic unity of words. Also, in syntagmas, these peculiarities go back, but phonetic and stylistic features go to the forefront.

A.Rajably notes that syntagma is not a unit of syntax, but it is necessary for providing information about it. Specifically, Y.Seyyidov does not comment on this theme. He sometimes connects the syntagma to oral speech, but sometimes notes the important role of phonetic and stylistic 
features along with syntactic features in its creation. Sometimes, he considers it (syntagma - H. A.) as neither phonetic, nor syntactical unit. Other times, he tells it is odd to deal with the relation forms of the words in syntagma. As for Y.Seyyidov, syntagmas are parts separated by interval in speech. Thus, this is irrespective of the relations and forms of words, and how they appear in different ways. He has generalized these forms as 1) word; 2) auxiliaries; 3) word combinations (in different types); 4) sentence (in different types); 5) two or more free words that do not cover word combinations and sentences. According to the scientist's mind, syntagmas also vary according to their attitudes in sentences and towards the parts of sentence. "Syntagma, however, includes:

1) Part of sentence,

2) Some parts of sentence,

3) A part of the composite sentence,

4) Address,

5) Dialect etc.” (Seyyidov, 1992)

In general, the separation of speech over syntagmas is closely linked to the purposes and meanings promoted. Cicero, a philosopher of the ancient age, said: "The longest possible complex word is that which can be uttered in a breath. These limits have been put forward by nature, and the profession puts forward other limits” (Античные теории языка и стиля, 1960). As it is regarded, the meaning, context, word circle, and the speaker's psychological position affect the speech to be split into syntagmas.

It should be noted that syntagma should not be equated or confused with a word combination. Word combinations are mostly derived by subordination relation, but syntagmas by a coordination relation. As it is clear, syntagmas vary depending on the types of relation, and are split into predicative and attributive syntagmas. They are mostly binomial. Though syntagmas have similar features with word combinations, they are different from word combinations according to their usage, circle, and based on some other characters. Syntagmas are analyzed according to the syntactical concerns and types of relationship among the members. Word combinations are related to syntactical relation types and the categorical kinds of a component. The components of word combinations cannot be replaced with other words. In addition, the components of syntagmas would not only be replaced, but the meanings also are not changed.

There are various thoughts about the places of word combinations in linguistics. As for the scientists, such as F.F. Fortunatov, A.M. Peshkovsky, M.N. Peterson and V.M. Sukhotin, word combinations must be the main explorative object of syntax. Also, the sentence problem should be studied under it (word combination - H. A.). 
Professor Gazanfar Kazimov states that syntagma consists of word combinations and groups being linked by syntactical relationships in a sentence and it acts as a single unit. His findings differ from the syntagmas and from one another. Thus, this is in accordance with the types of relationships, and it divides them into predicative and attributive types. It has a little similarity with academician A.A. Akhundov's opinions. Hence, he calls these syntagmas predicative and non-predicative which is related to their relation types.

Also, G. Kazimov considers the syntagma binomial. According to Kazimov, syntagmas vary from word combinations in accordance with their similar characters and some features. He mentions that word phrases are analyzed relating to the types of syntactical relationships and categorical character of a main component. Furthermore, syntagmas is related to the syntactical relationships among the components and relation types. The components of syntagma can be replaced with other words. Thus, the meaning remains the same, but this process is impossible in word combinations.

Some scientists note that word combinations are a static fact. Syntagmas are dynamic being a speech fact. "Word combination is a phrase simulating the static - grammatical combination of two essential units - but syntagma is the combination of words taking an active function in speech and a sentence”. (Скепская, 1979)

Apart from word combinations, syntagmas also have a predicative relation. This relation is fully reflected in A.A. Akhundov's opinions and considerations on syntagmas as mentioned above.

As it is shown, G. Kazimov has dealt with syntagma as a unit of syntax. Thus, the following conclusion was drawn based on the following:

“- Syntagma is binomial and incorporates two members;

- This or other member of syntagma can refer to another syntagma too;

- Syntagmas are characterized in relation to the existence of subordination between their components”. (Kazımov, 2004)

The last opinion reveals the difference between syntagma and a word combination again. It matches with the scientists' opinions whose names were mentioned above (especially A.Akhundov, Y.Seyyidov, and so on H.A). Therefore, it is necessary to state that G. Kazimov has not taken a phonetic, but a syntactic view of syntagma. Also, he further promoted his considerations over it. After looking through all of them, it was obvious that A. Akhundov has promoted more all-sided: both phonetic and syntactical opinions than the others. In addition, he has improved the concept of syntagma in the linguistics of Azerbaijan. A.Akhundov has destroyed all other thoughts. Considering what was mentioned, we possibly came to a 
conclusion that syntagma is mostly a unit of syntax. It should be noted that syntax does not only study the syntagma, but it also analyzes sentences.

It is already known that syntagmas are divided into predicative and non-predicative groups, being a unit of syntax. Predicative syntagmas match sentences, while non-predicative syntagmas cover word combinations. If syntax is a study about sentences and word combinations, then it is possible to consider syntax as a study about syntagmas too. It is eventually known from the works written about syntax. However, this field of study both analyzes the sentences and activates with the word combinations. Therefore, the thought of considering syntax as a study about word combinations and sentences is completely right.

The Russian linguistic theories (V.Scherba, V.Vinogradov) determine syntagma associated with speech acts. However, this is with phonetic and rhythmic characteristics of the information unity, the unity of interconnected information, and the tempo of speech. In contemporary Russian language schools, there is an occurrence of a paradigmatic shift in the research of syntagmas. Also, similar processes are characteristic of the Azerbaijani language school. Thus, this process is explained by a common interest in structural linguistics.

Relations between the paradigmatic and syntagmatic system are investigated in contemporary Azerbaijani language school (A.A.Akhundov, G.Kazimov, Y.Seyyidov etc.). Thus, this is in the same relation to the vertical and horizontal level language. The peculiarity of the internal structure of language is that it is entirely composed of a variety of linguistic paradigm, according to which any linguistic unit is a part of a particular paradigm. Members of the same paradigm trend back to the identity of the invariant. In addition, it varies due to the various problems in initial communication. Similarly, members of the Azerbaijani language paradigm of writing and speaking, engages in syntagmatic relationship of the speaker's elects. The difference between written and spoken language is explained based on the fact that the syntagmatic relations are less regulatory and dynamic in oral speech. Universalism of relative syntagmas in Russian is known as the nature of language. This is a multi-meaning of words (E.Kurilovich) that allows you to create interaction between the text and the interpretation of meaning. Universalism of syntagmas allows one to determine the cross-layer, integrated approach, which gives a new way to characterize the syntagma of Azerbaijani discourse. Therefore, this is in relation to the British discursive practice, and it show aspects of its functioning in the modern Azerbaijani language.

Word order system of the Azerbaijani language belongs to the Turkic family of languages. However, it is completely different from English language. As a result, comparative typological analysis of syntagmas based 
on the effect of the trends is taking place in English language, and not only in Indo-European. However, in Turkic languages, this means that English language is becoming a language of interethnic communication. A comparative typological analysis of syntagmas shows that the contemporary Azerbaijani language, traditionally, is rich. Thus, syntagmatic figures tend to speed up the information, which is the trend of convergence with English language. Language analysis of syntagmas of Azerbaijani language is taken based on the latest works of prose and poetry of Azerbaijani literature. Genre diversity also affects the function of the syntagma between these genres. Consequently, there is a difference: a poetic genre saturated syntagmatic models, less prosaic. Contemporary Azerbaijani prose describes the active use of relative syntagmas that it belongs to the category of syntax. Such an approach is determined by the rate of speech. It is divided in the first place, to sentences that express a complete thought. The sentences are further divided into words and phrases. Thus, in the course of the conversation, a natural division of syntagmatic speech takes place. In other words, syntagmas appears.

The syntactic phenomenon plays an important role in ordinary speech in the syntagmatic division of sentences. Each component of the complex sentences, the verbal components of speech, the grammatically independence of the members of sentences (introductory words and sentences), and the circumstances of time and place forms some syntagmas. However, in special speech, the sentence may not have such syntagmatic division. The role of relative syntagmas is aimed at perceiving the person for whom the main thing is not the subject of enunciation, but in obtaining information for action. Therefore, this method in the theories of linguistics is defined as the communicative certainty (Kommunikative Bestimmtheit).

Syntactic-relative syntagmas have a definite structure: a verb and adverb (circumstance), for example, in Azerbaijani language: ifadəli oxumaq, cəld qaçmaq, sürətlə sürmək, gözəl danışmaq etc. Another example can be seen in English language: speak quickly, write directly, read well, answer rudely, perform well, and so on.

The difference is that in Azerbaijani language, the adverb comes before the verb predicate. Thus, in English language, it is vice versa i.e. the adverb comes after the verb predicate. Receptive aspect is aimed in understanding. However, communicative certainty (Roman Ingarden, V.Izer) invites the recipient to co-authors. Communicative certainty arises when needed.

In the contemporary Azerbaijan linguistics, special scientific interest entails the study of the problems of paradigmatics and syntagmatics in the sphere of morphology and syntax. This interest is due to the fact that the traditional use of the terms "paradigms" and "syntagmatics" encourages 
them to communicate with the morphology and syntax. Naturally, the question is removed at the level of paradigmatic morphology, and at the syntagmatic level syntax. Morphological paradigms are real as much as syntactic syntagmatics. Therefore, the words of phrases and sentences are related to one another. This relationship gets incomplete. In addition, unambiguous explanation is an exclusively attributed syntax and, in rare cases, the lexics. In the phrase and sentence connections between words are several levels of linguistic structure, it is known that words as elements of morphology of language have certain associative properties. Syntagmatics language can be defined as a set of linguistic units. Thus, the system can be defined as a category of language and its associative capabilities in the implementation process of oral discourse. As paradigmatics, syntagmatics also belongs to all levels of language structure. However, if syntagmatics and paradigmatics is functioning at all units of language at all levels, there are paradigmatics morphology and syntagmatics syntax.

Consequently, syntagma is also explained as a phenomenon of semantic-syntactic speech. In this case, syntagma combined with a group of words in a sentence is united rhythmically and according to the meaning. Syntagma may consist of a single word, phrase, syntactic formulations, analytical units, as well as separate sentences. Syntagma may or may not match the phrase. Therefore, this is its essential difference. So, syntagma reveals itself in the sentence and it is evident in its partitioning. The phrase is not formed as a result of the division of words, but as a result of the combination of the sentence.

Depending on the text, the situation, the goals of the speaker, the substantive component of the sentence, and the same sentence can be divided into syntagmas in various forms. For example,

To watch nicely-nicely / is eye procedure,

To watch / nicely-nicely / is eye procedure,

To blush like a flower / is the rule of a person's face.

This method of syntagmatic articulation of speech is an interesting object of study of syntax. In fact, for a stable model of the phrase, it is regarded to be impossible. Syntagma has several types. Non-predicative syntagma agrees with the word "combination". Attributive syntagma is a non-predicative syntagma which consists of defining and definable. For example, a young man, a good singer, a kind doctor etc.

Object Syntagma: This type of syntagma is formed by the combination of the verb and the associated object. For example, to read a book, to do the work, to write a letter etc.

Relative Syntagma: This is the other type of syntagma, which emphasizes the connection between the verb and it indicates its circumstance. For example, Read well, run fast, write quickly etc. 
Predicative Syntagma: It is a study about sentence and is understood as a kind of syntagma. The sentence is considered to be predicative syntagma. For example, It is snowing. Fred came. We go to the cinema. He will come in time etc.

There is a method of investigation. Hence, this method separates the text into smaller components of the unit. Here, the latter, coexisting together, differ from each other, and can be connected with each other. These units are words in stories, morphemes within words, and sounds in sound combinations. Consequently, the division of speech to syntagmas is syntagmatics. Also, syntagmatics is the study about phrase (word combination).

As in other languages, in the Azerbaijani language, there are two types of syntagmas: complete (holistic) and incomplete (half-hearted, not holistic). As in the Azerbaijani language, the verb comes at the end of the sentence. Complete syntagma is also at the end of the sentence. Completed syntagma corresponds to predicative syntagma with some exceptions. Other syntagmas of sentence (including the division, compound words, words, grammatically unrelated to the members of sentence, etc.) are incomplete syntagmas.

Today, linguistics explores paradigmatics and syntagmatics in language synthesis. Basic postulates of this approach are the hypothesis that the paradigm at any level of linguistic structure forms a set of options based on a stable invariant. Therefore, they alternate in oral discourse. Signs form a system of relations in the form of paradigmatic and syntagmatic. Syntagmatic relationship is based on distributive potencies characters, their valence, and paradigmatic selection due to a particular element of the paradigm of signs. Hence, this is the reason the morphology of Saussure says "paradigmatic area", and the syntax is referred to as "syntagmatics area."

Furthermore, this paper is focused on dealing with relative syntagmas of phrases, and its nominative function as part of a combinatorial syntax. The availability in this area makes it possible in achieving a deep understanding of the nature of the compatibility of units of the Azerbaijani language in comparison to English. Thus, it will promote a universal metalanguage of combinatorial linguistics, which is under a development consideration of relative syntagmas. This is in the context of the combinatorial studies of Azerbaijani and English languages which deepens comparative-typological research. Also, the analysis of relative syntagmas facilitates the identification and description of the functions of the compatibility of nominative phrases.

Similar relative syntagmas enrich the notion of syntagmatic concept image. This nature of the relative syntagmas in the 60s of the twentieth century has been developed by Fillmore. It should be noted that this kind of relative syntagmas have not still received the theoretical definition. Their 
classification has not been represented. Rhythmic speech of languages differs not only with syntax, embodied in the word, but also with the rhythmic intonation nature of language. In syntagmatics pauses, absence or failure of rhythm also have artistic value and it serve as a way of showing syntagmatic. This aspect is considered by us in Azerbaijani and English languages. Particular importance of comparative analysis of rhythmic syntagmas will be in the translation practice. In this work, we will base on the teachings of theorists (N.Y.Danilevsky, O.Spengler, E.Sepir, F.Boas, L.Vaysgerberg etc.). Subsequently, their work reflected the principle of relativity. Also, it has a fundamental importance and is used in the formation of relativism in linguistics. It should be noted that at the beginning of the twentieth century, the American Anthropological School (F.Boas, E.Sepir) criticized the linguistic determinism. Later on, representatives of this school investigated the effect of the issue of linguistic differences on human cognition. This approach and achievements of the representatives of this school serves as one of the main methodological approaches in this paper. Furthermore, it serves as a comparative benchmarking of relative syntagmas in the Azerbaijani and English languages. According to the fact that these languages belong to different language families, which also influenced other languages of these families, the aspect of the analysis of trends introduced definitions, existence, and variations of relative syntagmas in the RomanGerman, Russian, and Turkic languages. This approach is due to the expansion of the modern language of space. Furthermore, it is also considered on the basis of mutual influences in multilingual linguistic space. Definite difficulty in the development of this problem is the fact that only since 2000, the consideration of relative syntagmas was possible in terms of the existence of this phenomenon in combinatorial linguistics. However, researchers in this field are primarily interested in the practical aspect of the application of relative syntagmas in teaching foreign languages. The theoretical justification of this phenomenon is due to the increased interest in the combinatorial properties of syntagmatic linguistic units. Hence, this is due to insufficient knowledge of problems. Therefore, the theoretical definition of relative syntagmas will promote the development of basic areas of General Linguistics of the Azerbaijani language. In addition, it will also promote the study of syntagmatic linguistic signs that determine the linguistic identity of the contemporary national picture of the world.

Rationale for a comprehensive approach to the formation of combinatorial linguistics, and in its context and latest developments of syntagmatics related to the researchers of syntagmatics, found an integrated approach to its research: linear (F.de Saussure), binary (Sh.Bally), mutual transition of its elements (F. Mikush), and their ability of integration. Thus, applied application of the theory of relative syntagmas will be reflected in 
the creation of the combinatory Azerbaijani-English dictionary. From this point of view, the study of relative syntagmas of the Azerbaijani language should be integrated into general scientific development of structural linguistics, theory of phraseology, and the context of the Azerbaijani linguistic school.

\section{Conclusion}

The phenomenon of syntagma and relative syntagmas in Azerbaijani and English languages was investigated, learned, and developed for the first time. Also, syntactic, semantic, and stylistic features of syntagma as a unit of syntax were classified according to their types. Their meanings were widely spoken of, and their importance was highlighted comprehensively. However, this unit which consists of two members of the combined words was used in the functions of determining and being determined.

The consideration of the internal structure of the language allows the making of a general methodological conclusion in forming a full-fledged linguistic representations of the signs of language. Also, the successful assimilation of studying the native language of the entire system must be the assimilation of knowledge as a paradigmatic and syntagmatic language system. So, syntagmatics and paradigmatics function at all units of language and at all levels. Hence, they are regarded as paradigmatics morphology and syntagmatics syntax. This fact is explained by the fact that the intellectual activities with signs of language (action selection, classification, combination, transformation, and so on.) are based on the knowledge of the paradigmatic and the syntagmatic relations of elements of the language system. However, these skills and knowledge provide a component of language as a linguistic process to the use of language in speech activity. This material can be used in the research and teaching activities of a given problem.

\section{References:}

Akhundov A.A. (1988). General Linguistics. (pp.149-150). Bak1, (In the Azerbaijani Language).

Jaffarov S.A., Garayev A.H., \& Jaffarova K.A. (1981). A Short Dictionary of European Originated Words. (pp.175-176, 236). Bak1, (In the Azerbaijani Language).

Kazımov G. (2004). Modern Azerbaijani Language, Syntax. (p.40, 496p). Bak1, “Aspoligraph LTD” MMC. (In the Azerbaijani Language).

Rajably A. (2003). Theoretical Linguistics. (p.515). Bak1, "Nurlan”. (In the Azerbaijani Language). 
Seyyidov Y. (1992). Word Combinations in the Azerbaijani Language, Second Edition with Additions. (p.408). Bak1 University Publishing House, (In the Azerbaijani Language).

Античные теории языка и стиля. (1960). (с.244). Баку.

Бодуэн де Куртэнэ И.А. (1963). Избранные труды по общему языкознанию, т.II, (р.198). Москва.

Виноградов В.В. (1952). Синтаксические взгляды и наблюдения академика Л.В.Щербы. (с. 56). «Ученые записки Московского университета», выпуск 150, Русский язык.

Гвоздев А.Н. (1958). Современный русский литературный язык, ч.II, Синтаксис. (сс.34 - 39). Москва.

Соссюр Ф. (2004). Курс общей лингвистики, (256 с). Москва: УРСС.

Реформатский А.А. (1955). Введение в языкознание. (сс.253-254). Москва.

Скепская Г.И. (1979). Введение в синтагматику. (сс.4-5). Москва.

Словарь иностранных слов, (1949). (р.595). Москва.

Ученые записки Московского Университета, вып. 150. (1952). Русский язык. (с.59). Москва.

Щерба Л.В. (1953). Фонетика Французского языка, (с. 87). Москва.

Ахманова, О. С. (1966). Словарь лингвистических терминов. (с. 408).

Москва.

Biber D., Johanson S., Leech G., Conrad S. (1999). Longman Grammar of Spoken and Written English. (354p.). London

Kobrina N.A., Korneyeva E.A., Ossovskaya M.J., Guzeyeva K.A. (1986).

An English Grammar, Syntax. (376p). Moscow

http: //www.langinfo.ru/ 